\title{
QUALITY AND HYGIENIC CORRECTNESS OF GOAT MILK IN THE SKOPJE REGION OF THE REPUBLIC OF MACEDONIA
}

\author{
Goce Cilev $^{1}$, Nikola Pacinovski ${ }^{2}$, Živko Gacovski ${ }^{1}$, Biljana Petrovska $^{1}$, Tamara Isjanovska $^{1}$ \\ ${ }^{1}$ University Ss. Klement of Ohrid, Faculty of Veterinary Medicine, \\ str. Prilepska bb; p.box. 150, 7000 Bitola, Republic of Macedonia, \\ ${ }^{2}$ "Ss. Cyril and Methodius" University in Skopje, Institute of Animal Science, \\ Blvd. Ilinden, 92A; P.O. box. 207, 1000 Skopje, Republic of Macedonia, \\ goce_cilev@yahoo.com
}

\begin{abstract}
The aim of this experiment was examine the quality and hygienic correctness of goat milk in Skopje region, $\mathrm{R}$. of Macedonia. The researches were conducted on 3 goat farms: "Taor", "Kozhle" and "Ajvatovci" the villages near by the Skopje, R. Macedonia. The experiment included 9 milk samples per each farm, in period April (total 27 samples) and the same situation in May 2015 year. Average Milk Fat Content (AMFC) and Average Milk Protein Content (AMPC) in the three goat farms in month April/2015 were $3.68 \%$ and 3.34 respectively, but AMFC and AMPC in the three goat farm in month May/2015 were $3.74 \%$ and $3.23 \%$ respectively. Average Somatic Cells Content (ASCC) in the three goat farm in month April $/ 2015$ were $924.667 / \mathrm{ml}$ milk and Average Somatic Cells Content (ASCC) in the three goat farm in month May/2015 were $518.667 / \mathrm{ml}$ milk. Average Bacteria Content (ABC) in the three goat farm in month April $/ 2015$ were $1.688 .667 / \mathrm{ml} \mathrm{milk,} \mathrm{Average} \mathrm{Bacteria} \mathrm{Content}(A B C)$ in the three goat farm in month May/2015 were 1.517.333/ml milk. About chemical composition of goat milk in Skopje region is in correlation of article 7 from Regulation for quality of raw milk (Gazette of RM No. 96/11), the same situation is about somatic cells in goat milk in Skopje region. But about the total number of bacteria of goat milk in Skopje region the results are not in correlation with Regulation for microbiological quality of raw milk and classified goat milk in the II class of quality. This work attemps to present the quality and hygienic correctness of goat milk in Скопје region and future measures to better quality of goat milk.
\end{abstract}

Key words: goat milk; quality; milk fat; milk protein; somatic cells; bacteria

\section{КВАЛИТЕТ И ХИГИЕНСКА ИСПРАВНОСТ НА КОЗЈО МЛЕКО ВО СКОПСКИОТ РЕГИОН, РЕПУБЛИКА МАКЕДОНИЈА}

Цел на ова испитување беше да се утврди квалитетот и хигиенската исправност на козјо млеко во регионот на Скопје, Р. Македонија. Испитувањата беа реализирани на три козарски фарми во Таор, Кожле и Ајватовци, населени места во околината на Скопје, Р. Македонија. Опитот опфаќаше 9 млекопроби од секоја фарма, во текот на месец Април (вкупно 27 проби), а исто толку проби беа земени и во текот на месец Мај, 2015. Просечниот процент на млечна маст и просечниот процент на протеини во млекото на трите козарски фарми изнесуваше 3,68\% и 3,34 5 последователно, додека овие вредности во текот на месец Мај, изнесуваа $3,74 \%$ и 3,23\%, последователно. Просечната содржина на соматски клетки на трите козарски фарми во месец Април, 2015 изнесуваше 924.667/мл, додека во месец Мај тој беше 518.667/мл. Содржината на бактерии во млекото на трите козарски фарми во месец Април изнесуваше 1.688.667/мл, додека во месец Мај, бројот на бактерии во 1мл козјо млеко, изнесуваше 1.517.333. Во однос на хемискиот состав, козјото млеко во скопскиот регион, е во согласност со член 7 од Павилникот за квалитет на сурово млеко (Сл. Весник на РМ, бр. 96/11), а слична е состојбата и во однос на содржината на соматски клетки. Но во однос на вкупниот број на бактерии во козјо млеко, во скопскиот регион, истиот не е во согласност со Правилникот за микробиолошки квалитет на суровото млеко, и истиот во однос на квалитетот, го класифицира како млеко од втора класа. Овој труд претставува обид да се претстави квалитетот и хигиенската исправност на козјото млеко, во скопскиот регион, како и да ги претстави идните мерки за подобар квалитет на козјото млеко.

Клучни зборови: козјо млеко; квалитет; млечна маст; млечни протеини; соматски клетки; бактерија 


\section{INTRODUCTION}

Goats are among the first animals were a domestic by man. Almost $75 \%$ of the world population consumed goat milk in the diet of people in significant quantities used goat's milk, especially in the Middle East. Goat breeding industry represents developed stock breeding in almost all Mediterranean countries within Europe (France, Spain, Italy, Greece, and Turkey) which pays significant attention to its development and industrialization. Goat breeding is also a developed branch in other Western European countries such as Switzerland, Netherlands, Germany etc. Dairy goat farming is a vital part of the national economy in many countries, especially in the Mediterranean and Middle East region (Park et al., 2007).

This livestock industry has a centuries-old tradition in Macedonia. Due to environmental factors in many regions in Macedonia, there is a type of vegetation suitable for goat breeding, wherefore these animals have provided subsistence of the population in the past centuries. The prevalence of goat is due to its capability of acclimatization in different climatic and environmental conditions, therefore providing cheap milk, meat and skin. However, the reason for their prevalence is the high capability of using bulky stern and its transformation in products with high nutrition value.

The systems used for production in goat breeding here are result of climate conditions, economic characteristics and planned farm sizes. In Macedonia there are many farms with labor mechanization through the usage of machine milking of goats although the extensive goat breeding system is the one that dominates in Macedonia. Unfortunately, the percentage is very small and there is still much to be done on subject of intensifying and modernizing goat breeding. In Macedonia, the potential for goat breeding development is reflected with the fact that according to data from Statistical Office for 2010 (Statistical Yearbook 2006-2010), the total agricultural area is $1,121,000$ hectares, of which 611000 are pastures and the rest $(509.000$ ha) arable land. Here comes the fact that much of the forests with high and low trunks in an advanced stage of its development (i.e. established forests) are also potential for goat breeding development. Primarily, this is due to the fact that in such forests goats can't cause major damage on plant vegetation.

Historically, the number of the goats bred in Macedonia was around 500000 heads, with the low for prohibited goat breeding (Official Gazette of NRM no. 38, 13.12.1948). This law had highly significant negative role in reducing the number of goats in Republic of Macedonia. The stagnation of this livestock industry continues until 1989 when another law so-called Law on goat breeding was promulgated (Off. Gazette of R.M. no. 21, 18. 05. 1989). In 2012 the number of goats in Republic of Macedonia was 63.585 heads of all categories, which is 7193 heads less and around $11 \%$ compared with the number of goats in 2011 (Annual Report of Agriculture and Rural Development, 2012). According to the Food and Veterinary Agency, Identification and Registration Unit of livestock there are 1800 farms that breed goats in Republic of Macedonia (Pacinovski et al., 2012). There are 6 genotypes (breeds) of goats present in Macedonia in the system for identification and marking of livestock within the Food and Veterinary Agency: domestic Balkan goat, Alpine, Saanen goat, crossbreeds with Alpine, crossbreeds with Saanen goat and genotype registered under the name of other population. According the same Agency out of the total quantity in 2011, 48\% of the total number of goats are domestic Balkan goats, 5,5\% are Alpine goats, 7,9\% are crossbreeds with Alpine goat, 7,8\% are Saanen goats, 3,4\% are crossbreeds with Saanen goat and the rest are recorded as other breeds of goats.

The world produced 10,231,000 tons of goat milk, which in total world milk production accounts for $2.00 \%$. However, in certain countries, the share of goat milk in total milk production is very high. For example, in Iraq accounted for 58\% in Cyprus and Libya with 50\%, Greece 26\% and Turkey $23 \%$. The production of milk in domestic population of goat ranges from 100 to 250 liters (Kozarovski, 1998), while in Alpina goats varies depending on the country where it is bred. An average milk yield of 800 liters was recorded in Alpine goats in farm-breeding conditions, while with producers with fewer goats up to 900 liters (Mekich et al., 2005). According to other studies, in United States is determined maximal milk yield of 2.215 in lactation. (Popovski and Stefanovska, 2002). The milk yield in Alpina breed of goat in Serbia was 752 liters for 271 days of lactation (Skalicki et al., 1998). This breed of goat has high capacity for acclimatization resulting in its presence in many European and non-European countries, serving as improver in creating dairy goats of its type. 


\section{MATERIAL AND METHODS}

As the basic material for testing was used aggregate milk from three farms in the vicinity of Skopje, who own the Alpine breed goats. The first herd of goats is located in the village Taor, Skopje, owned by Slobodan Simonovski with BCR (registration number of the holding) 151300103 , with a total of 70 dairy goats (Figure 1).

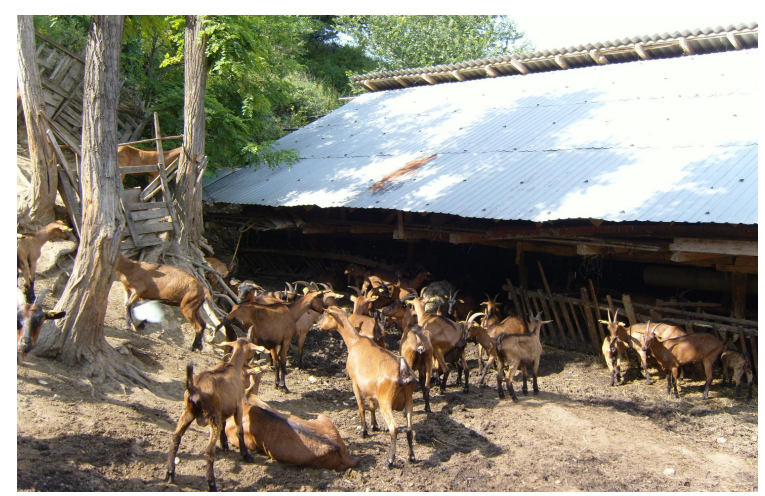

Fig. 1. Goat farm village Taor, Skopje (BCR: 151300 103)

Second flock is located in the village Kožle, Skopje, owned by Dime Georgievski with BCR: 282900481 , with a total of 140 dairy goats (Figure 2) and the third herd is located in the village Ajvatovci, Skopje, owned by Alexander Slivjanovski with BCR: 129303525 and with a total of 50 dairy goats (Figure 3 ).

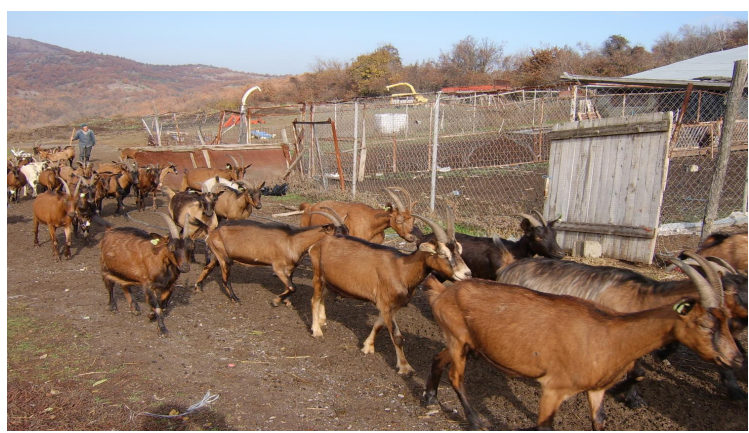

Fig. 2. Goat farm village Kožle, Skopje (BCR: 282900 481)

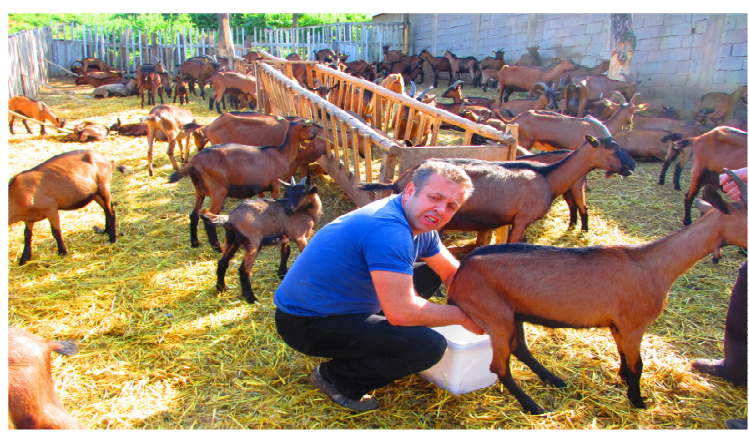

Fig. 3. Goat farm village Ajvatovci, Skopje (BCR: 129303 525)

Goat farm in Taor and Kožle breed combined (barn-Grasslands), while the goats on the farm Ajvatovci grown exclusively stable.

Since each of these farms were taken in 9 samples of milk, over two months (April and May 12015), which is the most intense period of lactation (Table 4).

Table 1

Number of samples taken for analysis of milk per farm and month

\begin{tabular}{|c|c|c|c|c|c|}
\hline \multirow[t]{2}{*}{ No. } & \multirow[t]{2}{*}{ Owner } & \multirow[t]{2}{*}{ Location of Farm } & \multirow[t]{2}{*}{ BCR } & \multicolumn{2}{|c|}{ Number of milk samples per month } \\
\hline & & & & April/2015 & May/2015 \\
\hline 1. & Slobodan Simonovski & Village Taor, Skopje & 151300103 & 9 & 9 \\
\hline 2. & Dimče Georgievski & Village Kožle, Skopje & 282900481 & 9 & 9 \\
\hline \multirow[t]{2}{*}{3.} & Aleksandar Slivjanovski & Village Ajvatovci, Skopje & 129303525 & 9 & 9 \\
\hline & \multicolumn{3}{|c|}{ TOTAL MILK SAMPLES: } & 27 & 27 \\
\hline
\end{tabular}

In two of the farms goats are milked manually (Taor and Ajvatovci), while one (Kožle) they are milking machine. However because of representativeness taken milk samples the day when milk was collected for analysis, all three farms goats would milk manually. Milk samples were taken in sterile plastic bottles in an amount of $50 \mathrm{ml}$ per sample. Samples were taken from the aggregate morning milk. The first sample was analyzed on the chemical composition, the second content of the somatic cells and the third milk sample was determined number of microorganisms (bacteria) in the milk. The chemical composition of milk was determined using the apparatus Foss Milkoscan 
4000 (Figure 4) (according to Guidelines for the functioning of instruments in the infrared spectrophotometry), production of Foss Electric Denmark. In determining the chemical composition of goat milk it was content determinations: milk fat, protein, lactose, fat free dry matter, total dry milk and water added.

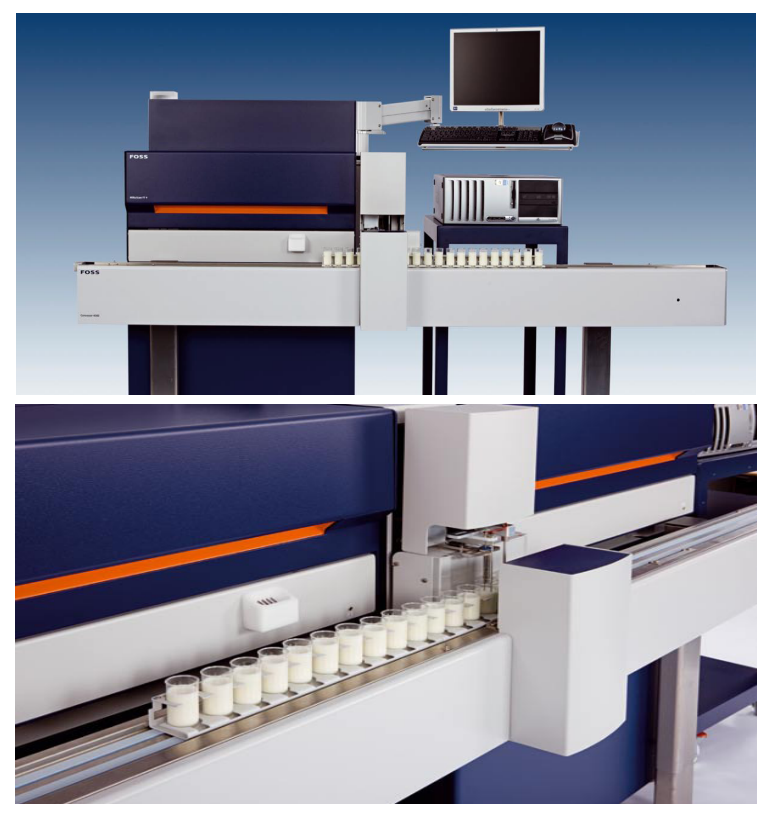

Fig. 4. Apparatus Foss Milkoscan 4000

The number of somatic cells was determined using the apparatus Foss Fossomatic 5000, enumeration of somatic cells (According to the Guidelines for Fluoro-opto-electronic counters), produc- tion of Foss Electric Denmark. Microbiological composition of milk was determined using a camera, Bentley Bactocount IBC 50-(Quantitative determination of bacteriological quality of raw milk). All analyzes were carried out in the reference laboratory control and sanitary safety of milk. The purpose of these tests was to determine the microbiological quality or safety of aggregate milk obtained from three randomly selected goat farms in the Skopje region, and on this basis to propose measures for its improvement.

\section{RESULTS AND DISCUSION}

\section{Chemical composition of goat milk in tested farms}

Based on the realized investigations on the chemical composition of goat milk on three farms during the month of April the highest percentage of milk fat is determined in milk from farm Kožle $(3.85 \%)$, and lowest in the milk from the farm Ajvatovci $(3.50 \%)$ (Table 2). In terms of protein content, the highest percentage $(3.70 \%)$ is determined to farm in Taor, and the lowest in the farm Ajvatovci (3.05\%). The content of lactose was highest in the farm Ajvatovci (4.71\%), while the lowest farm Taor (4.43\%). The highest content of fat free dry matter was found on the farm will be displayed $(8.69 \%)$, while the lowest farm Taor $(8.26 \%)$. The total dry matter in milk was also highest in the farm will be displayed (12.42\%), and lowest farm Taor (11.85\%). In terms of the content of added water, the result charter April in all three farms was zero, which indicated its full functionality in terms of physical water added.

Table. 2

Chemical composition of aggregate milk from three farms in months, \%

\begin{tabular}{|c|c|c|c|c|c|c|c|}
\hline No. & Farm & Milk fat & Protein & Lactose & DMNMF & Dry Matter & Added water \\
\hline & & \multicolumn{6}{|c|}{ Control April/2015 } \\
\hline 1 & Taor & 3.70 & 3.70 & 4.43 & 8.26 & 11.85 & 0.0 \\
\hline 2. & Kožle & 3.85 & 3.26 & 4.68 & 8.69 & 12.42 & 0.0 \\
\hline \multirow[t]{2}{*}{3.} & Ajvatovci & 3.50 & 3.05 & 4.71 & 8.51 & 11.90 & 0.0 \\
\hline & & \multicolumn{6}{|c|}{ Control May/2015 } \\
\hline 1. & Taor & 3.69 & 3.36 & 4.63 & 8.74 & 12.31 & 0.0 \\
\hline 2. & Kožle & 3.95 & 2.93 & 4.70 & 8.37 & 12.20 & 0.0 \\
\hline 3. & Ajvatovci & 3.57 & 3.41 & 4.88 & 9.03 & 12.49 & 0.0 \\
\hline
\end{tabular}


Regarding the examination of the chemical composition of goat milk from the three farms during the month of May, in terms of the percentage of milk fat was found identical situation as in April, the lowest ranking is determined in aggregate milk from the farm will be displayed (3.95\%), and lowest in aggregate milk from the farm Ajvatovci (3.57\%). For protein content, determined opposite situation regarding control of April, the lowest ranking is determined to farm Ajvatovci with $(3.41 \%)$, farm whose aggregate milk from April was determined lowest percentage of protein, and the lowest on the farm will be displayed in $(2.93 \%)$. The results for the content of lactose during this month are identical to those of April, the lowest ranking was established on the farm in Ajvatovci (4.88\%), while the lowest farm Taor $(4.63 \%)$. Fat dry matter during this control was highest in aggregate milk from the farm Ajvatovci $(9.03 \%)$ and get least represented was milk from the farm will be displayed $(8.37 \%)$. Same is the case in relation to the total dry matter in the milk, which was the highest in the aggregate milk from the farm Ajvatovci (12.49\%), and get least present in milk from the farm will be displayed (12.20\%).

The content of added water and monitoring for the month of May, the three farms was zero, which indicated its full functionality in terms of physical water added. The analysis values for the content of milk fat and protein average of three farms, in April they amounted to 3.68\% milk fat or protein $3.34 \%$, while in May, the average is $3.74 \%$ milk fat or $3.23 \%$ protein. On the other hand, an average of two months (April and May) in the three studied farms, in terms of the two most important parameters specified e rate of $3.71 \%$ milk fat and protein\% 3.28. It can be said that in terms of chemical composition, milk from these farms meet the conditions laid down in Article 7 of the Regulation on quality requirements for raw milk (Regulations on quality requirements for raw milk. (Official Gazette $N^{\circ}$. 96/11), where the minimum requirements regarding the content of milk fat in goat milk provided $2.80 \%$, compared to proteins (protein) provides minimal percentage of $2.50 \%$ and the content of fat free dry matter content is provided by the slightest of $7.50 \%$. All of these values in relation to individual preferences, the results obtained in our investigations beyond, thus confirming the fulfillment of this condition the quality of goat milk. Comparing these results in terms of chemical composition, with other similar, it can be concluded that they are within the intended content of milk fat, with certain exceptions. So according to Srbinovska (1999) and Banskalieva (2001), the percentage of milk fat is similar to that established in goat milk in Greece, Italy and France. Slightly lower compared to the one in Bulgaria, India and Spain. While the goat milk in England, determined the percentage of milk fat with large variations $(2.75-6.43 \%)$, which indicates above all the different racial composition of goats in this country, and consequently to the different content of milk fat. Namely, in this country, there is dairy breeds of goats like Saanen, having significantly lower content of milk fat, but cultivated and Anglo-Nubian dairy goat, which in spite of the high milk yield is known for the high percentage of milk fat, which is not rarely passes and $6.00 \%$. The situation is similar in Spain (Table 3).

Table 3

Chemical composition of milk by different authors expressed as a percentage (Sonja D. Srbinovska, Skopje, 1999)

\begin{tabular}{|c|c|c|c|c|c|}
\hline Country & Milk fat & Protein & Lactose & Dry matters & Authors \\
\hline England & $2.75-6.43$ & - & - & - & Storry et al., 1983 \\
\hline Bulgaria & 4.04 & 3.62 & 4.42 & 12.85 & Veinoglou \& Baltadjieva 1982 \\
\hline Greece & 3.44 & 3.35 & 4.30 & 11.76 & Voutsinas et al., 1990 \\
\hline India & 4.70 & 3.78 & 3.95 & 13.26 & Qureshi et al., 1981 \\
\hline Italy & $3.19-3.50$ & $2.78-3.08$ & - & $11.04-11.79$ & Castagnetti et al. 1984 \\
\hline France & $3.50-5.00$ & $3.5-3.9$ & $4.0-5.0$ & $12.50-14.50$ & Le Jeauen 1975 \\
\hline Spain & $4.44-6.94$ & $3.45-3.73$ & - & $13.19-15.94$ & Martin Hernandez et al., 1985 \\
\hline
\end{tabular}


The remaining parameters of the chemical composition (protein, lactose and dry matter), generally there are some discrepancies with those set out in these countries. Similar values regarding the chemical composition of goat milk cite Popovski \& Stefanovska (2002) (Table 4).

Table 4

Average values of chemical composition of goat milk (Popovski and Stefanovska, 2002)

\begin{tabular}{clc}
\hline \hline No. & Component & Part of $(\%)$ \\
\hline 1. & Milk fat & $3.07-4.50$ \\
2. & Protein & $2.40-3.76$ \\
3. & Lactose & $4.40-4.90$ \\
4. & Dry matters & $10.25-16.76$ \\
\hline
\end{tabular}

It should be noted that despite the genotype, diet is one of the most important paragenetical factors which has a major impact on the chemical composition of milk. Although the results in the chemical composition of milk from controlled farms are certain differences, however the results we have obtained is within acceptable limits. It is known that lactation curve goats generally is similar to that of the sheep and the labor move continuously downwards, and the parameters of the chemical composition of a slight increase, or move in the opposite direction. This ratio almost all parameters in our trials, with the exception of proteins in aggregate milk from farms and Taurus will be displayed instead of a downward trend upward. This is probably due to paragenetical factor diet, likely deficient in terms of protein content, which reflect the content of protein in milk. Given the fact that the proteins in the milk at the same time the most important component for the production of cheese (calcium para-casein), goat breeders should particularly very careful in the proportion of this component in milk. Therefore at regular monthly analyzes taken from the aggregate of all milk producers of goat's milk, which teach certain dairy milk, preferably farmers promptly inform about deviations and illogical that have compared the chemical composition of milk, how could a timely manner through diet to act to improve the chemical composition of milk, particularly in the percentage of improvement protein. In developed European countries and those with lower levels of development, and applying good agricultural prac- tice (GAP - Good Agriculture Practice) apply these methods of continuous education and information, as could breeders of livestock, ever to produce a quality product.

\section{Somatic cells in goat milk in tested farms}

Based on the realized investigations in terms of the number of somatic cells in goat's milk aggregate of the three farms during the month of April the highest number of somatic cells in $1 \mathrm{ml}$ is determined in milk from the farm in Taor (1.137 million/ml), and lowest in milk from the farm will be displayed $(778000 / \mathrm{ml})$. In aggregate milk from the farm Ajvatovci determined number of 859,000/ $\mathrm{ml}$ milk (Table 5). During the month of May, the schedule of farms is identical in terms of aggregate milk with the highest and lowest number of somatic cells, except that in this analysis of aggregate milk showed a significantly lower number of somatic cells in the farm will be displayed $(412,000 /$ $\mathrm{ml})$ and the farm with the highest number of cells in Taor $(618000 / \mathrm{ml})$. In aggregate milk from the farm Ajvatovci when this control is set number of $526,000 / \mathrm{ml}$ milk (Table 5). Analyzing the average results in terms of the contents of somatic cells for all three farms together, it can be concluded that the number of somatic cells in the month of April, the three farms together accounted for an average of $924667 / \mathrm{ml}$, while in May the average is $518,667 / \mathrm{ml}$.

Table 5

Number of somatic cells in aggregate milk from three farms, per month

\begin{tabular}{cccc}
\hline \hline No. & Farm & \multicolumn{2}{c}{ Number of somatic cells/ml } \\
& & April/2015 & May/2015 \\
\hline 1. & Taor & 1.137 .000 & 618.000 \\
2. & Kožle & 778.000 & 412.000 \\
3. & Ajvatovci & 859.000 & 526.000 \\
\hline \hline
\end{tabular}

Given the fact that the Regulation on quality requirements for raw milk in the Republic Macedonia (Regulation on quality requirements for raw milk. Official Gazette $N^{\circ}$. 96/11), not yet defined allowable number of somatic cells in ml milk, not going to comment on the results in terms of capacity. If compared with the regulations of the United States, where you are as recommended by the Food and Drug Administration that number is $1,000,000$ 
somatic cells to sheep and goat milk (Scruton et al., 2009, Orman et al., 2011), in which case we conclude that almost all terms analysis, the milk is fine, with the exception of the analysis of aggregate milk farm in Taurus, where the number of somatic cells is $1.137 \mathrm{million} / \mathrm{ml}$. Of course for this number should be alert to this farm that apparently there are goats in which abnormal secretion of the udder. This is necessary to make individual control and analysis of milk, in order to detect these goats questionable condition of the udder. After the discovery, they should be milked in a separate container, and their udders should be subjected to further treatment, in order to determine the type of infection. After determining the infection, these goats are subject to specific treatment in order to remove the infection and once again bringing to normal udder health and milk so I got usual composition.

\section{Total number of bacteria in goat milk in tested farms}

The content of total bacteria in milk actually evidence of pollution or hygienic safety of raw goat milk consumption. According to EU Directives $92 / 46$ and $94 / 71$, the upper limit for the number of bacteria in $1 \mathrm{ml}$ milk amounted to 500,000 cells $/ \mathrm{ml}$. On the other hand, according to the Rulebook on storage of raw milk and sampling for analysis and super analysis (Rulebook on storage of raw milk. Official Gazette $N^{\circ}$. 151/11), the number of bacteria (germs), goat and sheep milk are classified into three classes: Extra Class, I class and II class.

According to surveys Delgado-Pertinez et al., (2003), the number of bacteria in goat milk in the region of Seville in Spain, is the following order: $44 \%$ of farms Goatherd number of bacteria was less than $500,000 / \mathrm{ml}, 17 \%$ that number was between 500,000 and $1,000,000 / \mathrm{ml}$ and $22 \%$ of farms, the number of bacteria in the milk was between 1 and 3 million cells $/ \mathrm{ml}$.

Based on the realized investigations in relation to the number of bacteria in goat's milk aggregate of the three farms during the April peak of bacteria in $1 \mathrm{ml}$ is determined in milk from the farm in Ajvatovci (2.154 million/ml), and lowest in aggregate milk from the farm will be displayed (1.254 million/ml). During the month of May, is slightly different situation obtained the highest number of bacteria in the milk is determined to farm Taor (2.055 million / ml), while the lowest again in the farm will be displayed $(964,000 / \mathrm{ml})$
(Table 6). If we analyze the average results in terms of the total number of bacteria in milk for all three farms together, it can be concluded that the average number of bacteria in the month of April, the three farms together is $1,688,667 / \mathrm{ml}$, while in May the average is $1.571 .333 / \mathrm{ml}$.

Table 6

Total number of bacteria in aggregate milk from three farms, per month

\begin{tabular}{clcc}
\hline \hline \multirow{2}{*}{ No. Farm } & \multicolumn{2}{c}{ Total number of bacteria/ml } \\
\cline { 3 - 4 } & & April/2015 & May/2015 \\
\hline 1. & Taor & 1.658 .000 & 2.055 .000 \\
2. & Kožle & 1.254 .000 & 964.000 \\
\hline 3. & Ajvatovci & 2.154 .000 & 1.695 .000 \\
\hline \hline
\end{tabular}

According to Article 13 of the Regulation on the manner of storage of raw milk and sampling for analysis and super analysis where specified classification of goat and sheep milk, only aggregate milk from the farm will be displayed in the May of control, it belongs to a class of facilities, while the April I control class. In the other two farms (Taor and Ajvatovci) milk is lower quality, or milk from both controls in these two farms belonging to Class II. According to the results of two monthly checks, it can be concluded that the quality of goat milk in terms of microbiological correctness is unsatisfactory. It confirmed the result compared to the average content of bacteria in milk for all three farms together, months (April $1,688,667 / \mathrm{ml}$ and May to $1,571,333 / \mathrm{ml}$ ) milk according to the Rulebook on keeping the raw milk and sampling for analysis and super analysis (Rulebook on storage of raw milk. Official Gazette $\mathrm{N}^{\mathrm{o}}$. 151/11), belongs to a class II.

Analyzing individually, only milk from the farm will be displayed can be said that there is sufficient quality, but given that the milk of May, ranked in the extra class is close to vkupen broj na bakterii od $1,000,000 / \mathrm{ml}$, more needs to be working to improve the quality of aggregate milk of this farm. The condition of the other two farms (Ajvatovci and Taor) is critical, given that both controls on microbiological contamination, milk is classified into class II. It is evident that these two farms should be thoroughly begin work, in terms of improving the quality of milk. This is particularly important considering that it was farms which have 
extremely high quality breeding material from the Alpine breed. At the same time one of these farms (Kožle) produces cheese that sells in large markets in Skopje (Tinex and Vero), while the other (Taor), part of cheese sells diplomatic missions in Skopje, as well as several famous hotels in capital. As mentioned in the chemical composition of milk, it can be achieved through special programs of the Ministry of Agriculture that would have financed the purchase of equipment for the storage and cooling of milk, then through some micro projects that envisage continuing education of farmers in terms of improving quality mlekoto. Also it is necessary to mention here that such a role should be played by existing dairies in Republic of Macedonia as purchasers and consumers of milk, because in their favor is that milk has to be redeemed with solid kvalitet, and if you and the highest quality, especially in terms of microbiological safety of milk.

\section{CONCLUSIONS}

According implemented trials and the results thereof, may adopt the following conclusions:

- The number of goats in the Skopje region in 2013 totaled 3.545 heads of all categories, with a total milk production of 1368 tonnes and 1.368 million liters. According to the number of goats and milk production, this region is located in the middle compared to other regions in the country: the East, Southeast, Polog, Vardar, Southwest, Northeast and Pelagonia.

- In terms of chemical composition, ie content of milk fat, protein, lactose, fat free dry matter and total dry matter, aggregate milk from three farms studied in the Skopje region fulfilling the conditions laid down in Article 7 of the Regulation on quality requirements for raw milk, quality standards-run milk, dairy products and the use of their names, the quality and activity of starter cultures, Maya and other specific matters and the manner of their use, the manner of additional labeling of milk and dairy products, and the allowed deviation of weight in relation to the declared (Rules on the quality requirements for raw milk. Official Gazette $\mathrm{N}^{\circ}$. 96/11).

- In terms of content of somatic cells in milk aggregate in the Regulation on quality requirements for raw milk quality standards-run milk, dairy products and the use of their names, the quality and activity of starter cultures and other specific substances and way of using them, the manner of addi- tional labeling of milk and dairy products, and the allowed deviation of weight in relation to the declared (Rules on the quality requirements for raw milk. Official Gazette $\mathrm{N}^{\mathrm{o}}$. 96/11) is not defined allowable number of somatic cells in mililiter milk. Because of the lack of precision of these components in milk in this Regulation shall remain to the conclusion that under the regulations of the United States, which allows the presence of $1,000,000$ somatic cells/ml sheep's or goat's milk, the milk is fine, with the exception of the April analysis of aggregate milk Farm in Taurus, where the number of somatic cells is 1.137 million/ml, which exceeds the allowed limit.

- According to the results of microbiological analysis, it can conclude significant microbiological contamination of milk. Therefore we conclude that the quality of goat milk in the Skopje region, in terms of microbiological correctness is unsatisfactory. Only milk from the farm will be displayed in a satisfactory quality, but given that the milk of May, ranked in the extra class is close to total number of bacteria from $1.000 .000 / \mathrm{ml}$, more needs to be done to improve the quality of aggregate milk this farm.

- As a general conclusion from these studies is that goat milk in the Skopje region in terms of two (chemical composition and content of somatic cells) of the three parameters examined meets the intended criteria. In the future more attention should be paid to improving the microbiological safety of this type of milk to the moment when the price of milk will be determined according to this criterion, farmers breeders of goats, be prepared, and thereby achieve the highest degree of rentability.

- All that would be achieved by constant presence on the ground by all advisory services, institutions and experts in the country, how could farmers constantly reminded of these requirements and criteria. Of course in this regard, a significant contribution can be given by dairies, as direct beneficiaries and the controllers of milk quality.

\section{REFERENCES}

[1] Annual Report of Agriculture and Rural Development (2012). MAFWE.

[2] Banskalieva, V.: Fatty acid composition of milk fat triacylglycerols in three breeds of goat during lactation. Bulgarian Academy of Sciences. Biologie, Tom 54, No 9 (2001).

[3] Delgado-Pertinez, M., Alcalde, J. M., Guzman-Guerero, L. J., Castel, M. J., Mena, Y., Caravaca, F. (2003): Effect of Hygiene-sanitary Management on Goat Milk Quality 
in Semi-extensive Systems in Spain. Small Ruminant Research, 47, 51-61 (2003).

[4] Kozarovski, N.: Sheep and Goat Breeding. University "St. Kliment Ohridski”, Bitola, 1998, p. 252.

[5] Mekich, C., Krajinović, M, ZHujović, M.: Development of intensive goat production. Symposium of milk production and processing. Belgrade, Work collection, p. 9-17. (2005).

[6] Orman, A., Gunay, A., Balci, F., Koyuncu, M.: Monitoring of Somatic Cell Count Variations During Lactation in Primiparous and Multiparous Turkish Saanen goats (Capra hircus). Turk. J. Vet. Anim. Sci. Tubitak. Vol. 35, $\mathrm{No}^{3}$, pp. 167-175 (2011).

[7] Pacinovski, N., Dojchinovski, T., Petrovska, S., Kochoski Lj., Kozarovski, N., Dumova-Jovanoska, E.: A survey of forming regional reprocentre of sheep and goats in east region. My country, Ohrid, 2012, pp. 1-272.

[8] Park, Y. W., Juarez, M., Ramos, M., Haenlein, W. F. G.: Physico-chemical characteristics of goat and sheep milk. Small Ruminant Research, 68, pp. 88-113 (2007).
[9] Popovski, K., Stefanovska, J.: Goat Breeding. Vita-Vet. Skopje, pp. 1-105 (2002).

[10] Regulation on quality requirements for raw milk. 2011. Official. Gazette $N^{\circ} 96 / 11$.

[11] Rulebook on storage of raw milk. 2011. Official Gazette $\mathrm{N}^{\mathrm{o}} 151 / 11$.

[12] Scruton, D., Rood, Kerry, Junkins, Laurel., Moyer, B.: Guide to Crisis Management of Somatic Cell Counts in Goats. Vermont Agency of Agriculture. Food and Markets. pp. 1-9 (2009).

[13] Skalicki, Z., Urošević, M., Ostojić, M., Mekić, C.: Milk production of French Alpine goat. Journal for scientific agricultural research, 59 (1-2), pp. 17-22 (1998).. Belgrade.

[14] Srbinovska, S.: Technological properties of goat milk depending on thermal process and orientation of cheese production. Doctoral thesis, Faculty of Agricultural Sciences and Food, Skopje, 1999, p. 130.

[15] Statistical Yearbook 2006-2010. State Statistics Office. 